\title{
Isolation and Characterization of hydroxyapatite from Giant Travelly (GT) Fish bone Waste as a Biocheramic Materials for Aplication of Implant Dental Body
}

\author{
Melsiani R F Saduk ${ }^{1}$, Duran Hore ${ }^{1}$, Agustinus Deka Betan ${ }^{1}$, Fransisko Piri Niron ${ }^{1}$ \\ \{melsianisd@gmail.com,yolan_yoel@yahoo.com,agustinusbetan@gmail.com, \\ fransiskoniron@yahoo.co.id\} \\ Politeknik Negeri Kupang, J1 Adi Sucipto PO Box 139 Penfui Kupang 1,2,3,4
}

\begin{abstract}
The use of dental implants is now wider, and has various types of dentures. Today, titanium is still the 'gold standard' for the manufacture of dental implants because of the high long-term clinical success rate. However, concerns arise from titanium metals that have caused allergic reactions and sensitivity. Therefore, the purpose of this study was to produce HA isolates that have characteristics that meet the requirements of proactive raw materials in making biochemical body implants through isolation and characterization of HA from GT fish bone waste. The planned research activities include preparation of fish bone test samples, HA characterization with FTIR, XRD, and XRF. Based on XRF analysis it was found that $\mathrm{CaO}$ compound had the biggest percentage which was $68,96 \%$. FTIR analysis indicate the presence of $\mathrm{OH}$ groups, $\mathrm{CO} 3$ and $\mathrm{PO} 4$. And xrd analysis shows that the crystallite phase formed is hexagonal.
\end{abstract}

Keywords: bioceramics, GT fish bone, hydroxyapatite, dental implants

\section{Introduction}

The use of dental implants (dental implants) is now increasingly widespread, and is the best alternative of various types of dentures. The principle of dental implants Associated with other types of dentures that improve the function of mastication. The difference is that there are only different types of dentures available, while the implant consists of two parts, namely the infrastructure that is moved in the bone and is being prepared to contain the tooth root and the superstructure that functions to activate the crown.

Currently titanium metal is still the 'gold standard' for the manufacture of dental implants due to the high level of long-term clinical success. The implant material should ideally meet the requirements: biocompatible, corrosion resistant, fracture resistant. The implant design principle must be in accordance with the physical properties of the implant material. The materials used for the manufacture of dental implants can be categorized according to their chemical composition or the biological response produced when the material is implanted into the body. From a chemical point of view, dental implants can be made of metal, ceramics, or polymers [1]

Research on alternative materials to replace bone and tooth damage has been done, one of which is the use of synthetic synthetic materials, namely bioceramics, polymers or 
metals[1]. Bioceramics have been used successfully to repair, reconstruct, and replace diseased parts or damaged body parts, especially bones compared to polymers or metals [2]. Bioceramic material is not toxic, has biocompatibility, and bone bonding or good bone regeneration properties [3]. Bioceramic material commonly used in the field of tissue rehabilitation is hydroxyapatite

Hydroxyapatite Ca10 (PO4)6(OH)2 (HA) is an apatite mineral compound which has a hexagonal structure. HA is the most stable crystalline phase of calcium phosphate under normal physiological conditions [4]. Hydroxyapatite is a natural inorganic element derived from bone which is used to regenerate bones, repair, fill, add and reconstruct damaged bone tissue and also reconstruct in soft tissue [5]. Hydroxyapatite can be corals.

Hydroxyapatite material is good for bone transparency because it is bioactive which has the ability to adapt to the recipient's body (biocompatible) and has the character to unite and form with human bone ties or matrix (bioactive) and stimulates the obtained by isolating from natural resources such as cow bone waste[6], shellfish, eggshells and growth of new bone around network.

In this research, Giant Travelly fish bone waste will be used as a natural source to isolate and characterize hydroxyapatite with various considerations. First, the availability of abundant GT fish bone waste in Kupang. second, fish bone waste is cleaner or easier to clean from impurities (meat, fat, collagen) which are difficult to clean from cow bones. Third, the availability of fish bone waste is available all the time so it can be considered a renewable raw material.

\section{Experimental Procedure}

In this research descriptive descriptive research method was used. Where the research subject is GT fish bone waste and the object of research is Hydroxyapatite and its characteristics.

\subsection{Research Tools and Materials}

The tools used in this research include autoclave, digital balance, magnetic stirrer, ball mill, mortal and pastel, cup, beaker glass, erlenmeyer, measuring cup, funnel, dropper, filter, filter paper, aluminum foil, Fourier Transform Infra Red (FTIR), and X-Ray Diffractions (XRD) while the materials used in this study include GT fish bones, aquades, sulfuric acid, ethanol, and $\mathrm{HCl}$

\subsection{Sample Preparation}

The fish bones of GT waste cleaned by heating in an autoclave at a temperature of $274^{\circ} \mathrm{F}$ for 2 hours so that the collagen component of soft and easily separated from the bone. Collagen removed bone is powdered further refined by size 100 mesh. Each 2 grams of powder is added $4 \mathrm{~mL}$ of $\mathrm{HCl} 3 \mathrm{M}$ and 3 drops of concentrated sulfuric acid, then added $2 \mathrm{~mL}$ $70 \%$ ethanol and subsequently centrifuged for 10 minutes. The results of centrifuged and then filtered with a Buchner funnel if it does not settle or cannot be separated manually. This process aims to lose non-apatite components. 


\subsection{Fourier Transform Infrared (FTIR)}

FTIR is better known as the spectrometer method. Basically the FTIR spectrophotometer is the same as the IR disperse septrtrotometer, the difference lies in the development of the optical system, before the infrared beam passes through the sample. Some infrared radiation is absorbed by the sample and some is passed (transmitted). The resulting spectrum is the absorption and transmission of molecules and creates molecular traces of the sample[7]

\subsection{XRF}

The XRF tool is operated so that the sample holder spinner will move towards the holder and stop automatically. The DX-95 digital display will show numbers. Measurement conditions at a voltage of $14 \mathrm{kV}$ and a strong current of $90 \mu \mathrm{A}$. Sample measurements will take up to 5 minutes.

\subsection{Ray Diffraction (XRD)}

To identify the structure of HA samples is done using X-ray diffraction (X-Ray Diffraction). This XRD is used to produce certain diffraction patterns that can be used in qualitative and quantitative analysis of the material. In accordance with Bragg's law, when the $\mathrm{X}$-ray is positioned in such a way and affects the sample, the sample atom will deflate the Xray and so is captured by the detector[2].

\section{Results and Discussion}

\subsection{Sample Prepared}

Fishbone were obtained from Giant Travelly fish. It was then and turn into the powder of hydroxyapatite. The powder of GT HA are claimed at a temperature of $274^{\circ} \mathrm{F}$ for 2 hours [8].

\subsection{The Content of Compound in GT Fish Bone}

Based on the results of the XRF analysis obtained several compound components found in GT bones. As shown in Table 1.

\begin{tabular}{cc} 
Table 1. Compound of GT bones based on XRF Analysis \\
\hline Compound & Concentration Unit (\%) \\
\hline $\mathrm{P} 2 \mathrm{O} 5$ & 26,1 \\
$\mathrm{SO} 3$ & 0,23 \\
$\mathrm{~K} 2 \mathrm{O}$ & 0,1 \\
$\mathrm{CaO}$ & 68,94 \\
$\mathrm{Fe} 2 \mathrm{O} 3$ & 0,10 \\
$\mathrm{CuO}$ & 0,029 \\
$\mathrm{ZnO}$ & 0,008 \\
$\mathrm{SrO}$ & $\mathrm{O}, 64$ \\
$\mathrm{ZrO} 2$ & 0,1 \\
$\mathrm{Ag} 2 \mathrm{O}$ & 2,2 \\
$\mathrm{Ln} 2 \mathrm{O} 3$ & 1,1 \\
$\mathrm{Sm} 2 \mathrm{O} 3$ & 0,15 \\
$\mathrm{Yb} 2 \mathrm{O} 3$ & 0,22 \\
$\mathrm{Re} 2 \mathrm{O} 7$ & 0,04 \\
\hline
\end{tabular}


The XRF analysis results showed that there were around $68.94 \%$ of calcium oxide present in the GT bone waste. According to Nagai (2004) in Kim and Mendis (2006), the organic component in the form of collagen in fish bones comprises $30 \%$ and the remaining 60 $70 \%$ is an inorganic component in the form of calcium.

concentration

\subsection{XRD Analysis}

The research results obtained hydroxyapatite material which is isolated from gt bone waste with hydroxyapatite characterization results using XRD analysis test. The results of XRD hydroxyapatite bone fish GT characteristics in Figure 1 below begin from $10^{\circ}$ to $90^{\circ}$.

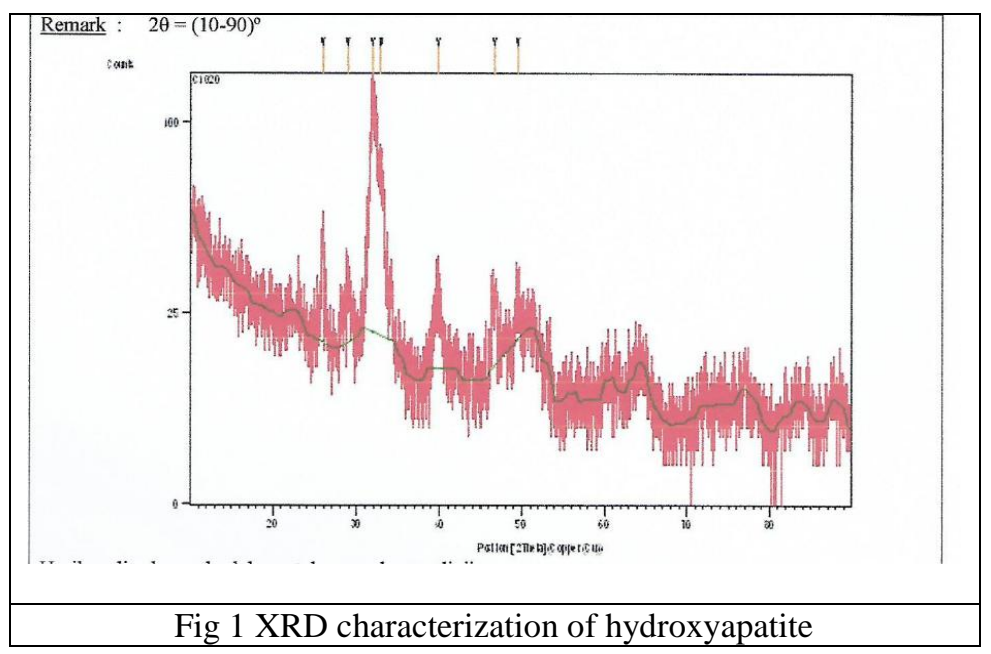

Figure 1 shows that the GT bone has a diffraction peak which indicates the presence of a crystalline phase. The structure of crystalline phase is hexagonal (based on card of Powder Diffraction File).

\subsection{FTIR Analysis}

The results of FTIR characterization of hydroxyapatite fish bones gt can be seen in Figure 2. The range of 400 to $4000 \mathrm{~cm}$ to see the bonding of molecules in hydroxyapatite, in general there are three ions formed in hydroxyapatite namely $\mathrm{Ca}-\mathrm{O}$,hydroxyl $(\mathrm{OH})$ and phosphate (PO4) 


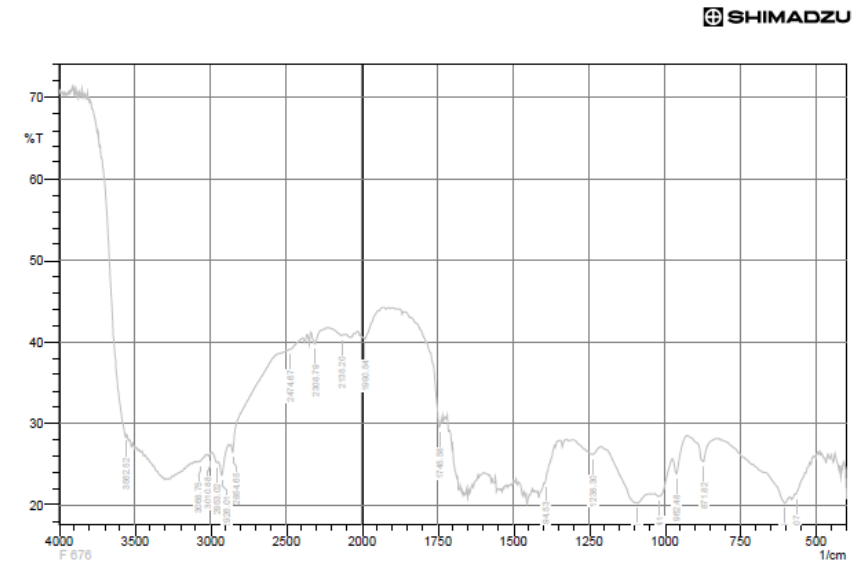

Fig 2. FTIR characterization of hydroxyapatite from GT Fish bones

\section{Conclusion}

HA isolates from gt bone waste have characteristics that meet the requirements as bioactive raw materials in the manufacturing of bioceramics of dental body implants through XRF, XRD and FTIR analysis.

\section{Acknowledgement}

The authors would like to thankPoliteknik Negeri Kupang for the financial support throughthe RUTIN research programme. A thank you also goers to my friend in Lab. Materials UMM for them assistance during this research

\section{References}

[1] Ylinen, Pekka, 2006, Application of Corraline Hidroxyapatite With Bioresorbable Contaiment and Reinforcement As Bone Graft Subtitute, Academic Disertation, University of Helsinki, Findland

[2] Kusrini, E., and Sontang, M. 2012. Characterization of X-Ray Diffraction and Electron Spin Resonance: Effects of Sintering Time and Temperatur on Bovine Hydroxyapatite. Radiation Physical and Chemistry. Vol. 81. No. 1. Pp. 118- 125.

[3] Mollazadeh, S., Javadpour, J., and Khavandi, A. 2007. In Situ Sysnthesis and Characterization of Nano-Size Hdroxyapatite in Poly (Vinyl Alcohol). Ceramics International. Vol. 33. No. 1. Pp. 1579-1583.

[4] Windarti,tri dan Yayuk Astuti,2006. Pengaruh Konsentrasi Ca2+ dan PO43- pada Pembentukan Hidroksiapatit di Dalam Matriks Selulosa Bakterial. Kimia FMIPA Universitas Dipenegoro

[5] Darjito, Arum C.D. dan Sri W. 2014. Sintesis Biokeramik Hidroksiapatit (Ca10(PO4)6(OH)2 dari Limbah Tulang Sapi Menggunakan Metode Sol-Gel. Kimia Student Journal. Vol. 1, No. 2, pp. 203-209. 
[6] Fahimah, A.D.W., Wardiani, S., dan Musbah, M.K. 2014. Pengaruh Perbandingan Masa Ca:P terhadap Sintesis Hidroksiapatit Tulang Sapi dengan Metode Kering. Jurnal Mahasiswa Kimia. Vol. 1. No. 2. Hal. 196-202.

[7] Thermo, N. 2011. Introduction to Fourier Transform Infrared Spectrometry. Thermo Nicolet Corporation:USA

[8] Karyasa, I W. 2018. Environmental Oriented Inorganic Chemistry Practicum. Singaraja: Undiksha Press, pp. 39 